\title{
Palahniuk's Tyranny of Language and Ontological Minimalism
}

\section{Daniel Hourigan}

$\mathrm{T}$ his paper reflexively focuses Chuck Palahniuk's novel Diary on the violence of language and civilisation. Palahniuk is a contemporary American author whose prose follows a style synonymous with other writers such as Gordon Lish, Amy Hempel, Tom Spanbauer, and Mark Robinson, and the broader literary movement of American Minimalism that has Ernest Hemingway and Ezra Pound as its progenitors. Many, if not all, of Palahniuk's narratives portray scenarios of domestic terrorism. But rather than write this terror using a simple third-person narrative voice, Palahniuk writes with a Minimalist aesthetic that is properly 'Romantic' in its acceptance of chaotic Nature as an authentic existence which is barely concealed by either civilisation or mundane everyday life. In essence, Palahniuk's domestic terrorists expose what we dare not admit to ourselves. The contention of our discussion below is that Palahniuk's Diary is a type of auto-critique of Palahniuk's own systemic violence against traditional narrativisation that creates a unique system of relations between the reader and the story.

Before we can turn directly to Diary it is first necessary to outline what exactly 'minimalism' means in terms of the prosaic techniques that Palahniuk's deploys in his writing. Broadly speaking, literary Minimalism distils a concentrated narrative by discarding regular techniques of descriptive narrativisation in favour of more experimental methods. These methods include: the repetition of key themes and motifs, intentional misspelling and misphrasing, an amoral narrativisation that eschews any terms of valuation, and the avoidance of abstractions such as time and measurement. In short, the term 'Minimalism' metaphorically reflects the way that this literary style uses a minimum of narrative construction. ${ }^{1}$ And while these Minimalist techniques work at the level of Palahniuk's narrative they also serve to construct a world for the reader by laying it bare and without moral judgement or regular methods of measuring narrative space.

Very briefly, Diary is the story of a failed artist called Misty Wilmot and the 'coma diary' she keeps for her loathed husband Peter Wilmot. The narrative is set on Waytansea Island where an inter-generational plot to revitalise the island becomes sublimely terrifying and deadly. The narrative is littered with references to art history, psychoanalysis, anatomy, and other

${ }^{1}$ Chuck Palahniuk, Non-Fiction (True Stories) (London: Vintage, 2004), 145. 


\title{
D. HOURIGAN
}

disciplines that neatly fit into discussions of artistic production, technical skill, and art criticism.

In a critical light, Palahniuk's Diary is a narrative work that provides an auto-critique of Palahniuk's approach to language at the level of its narrative and the deployment of its words. This auto-critique can be seen initially in the way that Palahniuk's prose operates by revealing the excesses and deficiencies of language because it is written in the Minimalist mode outlined above. This Minimalism emphasises the failure of words to directly correspond to their meanings by undermining the suppositions of a given statement. In one example, the emphasis appears as follows: “'An eighteen-year-old girl,' what does that mean?" 2 Numerous other examples abound in the work, ${ }^{3}$ but as these other examples are far too numerous to discuss at adequate length we will focus on a few select examples in this discussion. The critical point, however, is that this Minimalist condition of the prose points to an aesthetics insofar as the language used by Palahniuk entrenches the reader in an aesthetic cocooned in the aesthetics of prose. In Diary this is revealed in the endless self-analysis of signification through Freud and Jung, graphology and Stendhal syndrome, anatomy and phrenology, to name a few. ${ }^{4}$ This self-analysis is not merely part of the story; it is part of the formal composition of the narrative itself. At the level of narrative, the aesthetics of Palahniuk's prose are in-aesthetic, somewhere between aesthetic judgement (the act of reading) and the nonaesthetic (the mechanics of understanding the prose) that hollows out the usual rules of description because it is a Minimalist work written in a Minimalist style. At a more formal level of composition this means that the usual descriptive mode of narrative fiction is auto-critical of its own purpose. The aesthetics of the prose provide this auto-critique in its constant references to the insufficiency of language in a work composed of language. Herein, Diary is a work of fiction that exposes its composition because it constantly attempts to stand outside itself as though it were excessive, too much for language to dominate in its own terms.

Given the excessivity of Diary outlined above, the prose of Diary subsequently becomes ontologically problematic because it destabilises language itself. Because Diary is written in a Minimalist style, the narrative disclosure of the world in the book by way of language is not pinned on a suspension of disbelief. Instead, the elucidation of doubt by way of questioning the sufficiency of language leads Diary to situate language as a purely formal problem to be solved at the level of the reader because they are engaged in understanding the language presented. This ontological purification of language reflects what Freud termed displacement and condensation: the rejection of description in the signification of Diary-as-a-story (its Minimalism) displaces this 'narrative work' onto the pared down composition where it condenses as the 'reader's work'. Herein Minimalist prose offers no judgements to orient the

\author{
${ }^{2}$ Ibid., 144. \\ ${ }^{3}$ Ibid., 4, 24, 29, 32-33, 51, 54, 56, 64-65, 103-105, 124, \& 134. \\ ${ }^{4}$ Ibid., 56, 64-65, 103-105.
}


reader's subjective sensibility and instead forces this sensibility/subjectivity to make sense of the narrative. This procedure is what makes Palahniuk's prose properly focused on an in-aesthetic excess against the distant narrative form of third person voice, ultimately only allowing a point of view from the position of an 'I', 'you', or 'we' for the fantasisation of the reader. In The Interpretation of Dreams Freud announces this type of condensed position of the reader as a signal for the expression of "a merely wishful common element" in place of "a displaced common element." 5 Applying Freud's insight to Diary, it is clear that the position Palahniuk puts his readers in is a materialist fantasy: a position that exceeds the materialist concern with aesthetics by burrowing deeper into the question of the subject-as-reader. We can simplify this insight as follows: accepting that Palahniuk's writing is real and comprehendible this work always presupposes its audience wherein these readers are a 'wish' of the writing anchored in the general dynamics of its material composition but this wish becomes invisible when we look directly at particular sections of Diary.

The instability of language that is accentuated by Diary necessitates the reader's engaging in 'work' to keep the narrative comprehendible. Yet such labour is clearly not at the level of the narrative but instead at the level of conceiving of language. It is worth underlining this point because Palahniuk ostensibly rejects language as a tool that the speaking being uses. Rather, it points to the way that signification —at least in the Minimalist mode—-speaks through the speaking being. If 'less becomes more' for Palahniuk, I would be tempted to add that 'language speaks us'. The condensation of the displaced 'narrative work' in the reader's imagination fundamentally changes the time of the narrative: we go from marking the passage of time through the judgements of the prose itself to barely a hint of duration except through the intervention of the reader's reflection.

This reflection brings us to the fourth procedure of Palahniuk's prose: that this sense of time which arranges narrative sense is speculative. We should understand speculation here with all of the importance given to it by German Idealist philosophers such as Schelling, Fichte, and Hegel: Minimalist prose is jarring to read because time itself is marked by the intervention of judgement. And the only reason the reader intervenes is because they must. Diary skewers the reader through its in-aesthetic excesses, such as its litany of anatomy; to quote one such instance:

By the time you read this, you'll be older than you remember... The 'orange peel' texture of your chin, these 'popply' bumps are caused by your mentalis muscle. Your 'pouting' muscle. Those frown lines you see every morning, getting deeper, running from each corner of your mouth down to the edge of your chin, those are called marionette lines. The wrinkles between your

5 Sigmund Freud, The Interpretation of Dreams, trans. by James Strachey (London: Penguin Books Ltd., 1991), 434. 
eyebrows, they're glabellar furrows. The way your swollen eyelids sag down is called ptosis. Your lateral canthal rhytides, your 'crows-feet', are worse every day and you're only twelve fucking years old for God's sake. Don't pretend you don't know what this is about. This is your face. ${ }^{6}$

This fourth procedure binds the reader's speculative imagination to the interiority of the narrative. If one finds themselves reading this passage and reflecting on their face then we are 'in' the aesthetics of Diary. A study of Palahniuk's novel Diary goes awry if it merely situates itself to debate the aesthetics or formal representations of the work. This reading misses that Palahniuk already forces the reader to consider their own identification with the narrative, the condensation of judgement in their imagination.

The in-aesthetic excess promoted by Palahniuk's writing violently destabilises the literary narrative voice to produce an insidious ambiguity: when should the reader's judgement intervene? Romantic Minimalism short-circuits this ambiguity by situating the reader's judgement in a speculative voidspeculative because it is the conception of language that is at issue, not the diegesis. The reader is void because the usual problem of reading wherein 'you never see the bullet coming' is substituted by the properly speculative intercession of the reader's judgment. Palahniuk brings the reader into his stories to labour in service of the narrative even though the reader stands outside the book itself. This labour is 'speculative' in that it marks the passage of time and morality: past, present, and future; and is underwritten by the logic of displacement and condensation. Moreover, this short-circuit leads Palahniuk to reveal that the craft or techne of critical judgement is 'effervescent' rather than deliberative or intentional. Such a framing of judgement is already given to us by Freud's analysis of dreams, and herein it flag that Palahniuk writes the reader's fantasisation into the belly of his work through the effervescent manifestation of an in-aesthetic excess.

One may do well to ask, however, what then is characteristically violent of these four procedures? We are dealing with words on a page and the corporeality of reading after all, not the violent bloodshed of armed conflict. Contemporary thought tends to understand 'violence' as an action marked by immense force and often destruction yet here we are charging Palahniuk with creating a 'systemic violence' that effectively introduces violence into his narratives in such a way that it exceeds polite description. The violence in Palahniuk is bound up with his techne, the way he writes and the underlying structure of this writing as it is approached by the reader. I am making use of this old Greek word, techne, for its philosophical import as it distinctly facilitates the making and unmaking of artistic processes. In this framing, systemic violence is not the result of description but of the formal character of the structure that permits description in the first place. And herein the curious feature of Palahniuk's writing is that it explicitly unveils three levels of violence

${ }^{6}$ Chuck Palahniuk, Diary (London: Vintage, 2004), 4. 
in its formal character: the violent chaos of the Romantic vision of sublimely charged Nature, the violence of civilisation in the way that it facilitates social and political terror, and the systemic violence of forcing the reader to intervene in Minimalist prose.

With the former Romantic vision and the latter Minimalist mode already elaborated upon, it is now necessary to turn to the 'middle term' as it were: the violence of civilisation that makes space for social and political terror. Palahniuk's writing is often cast as 'nihilistic'. But this labelling of nihilism is imprecise. The nihilistic procedures of Palahniuk's plots, narratives, and characters are always revealing the chaotic vortex beneath the austere assurances of civil society. This recourse is foremost Romantic, not nihilistic. And Diary eschews nihilism through its endless references to the poetic mania of Peter Wilmot.

In Diary, we are told that the character of Peter Wilmot, Misty's comatose husband, spent time prior to the opening of the narrative refurbishing houses, and in these houses he hid rooms covered with fanatical raving. These rooms, these dark places, bob up to the surface of Diary with a sense of untimeliness. Peter has entered the resident's homes in good faith and vandalised the space, motivated by his being overwhelmed by the terror that Waytansea Island's families intend to perpetrate.

Peter's rooms are what Palahniuk refers to as a 'chorus', a recurring theme that brings forward the kernel of the narrative. But what is being repeated here? The rooms of Peter Wilmot are dark places where the entire space has been overtaken by someone's graphic mania. To quote:

These summer people, poor Misty, she tells them, Mr. Wilmot wasn't himself for the last year or so. He had a brain tumor he didn't know about for-we don't know how long. Her face still pressed to the hole in the wallpaper, she tells this Angel Delaporte how Mr. Wilmot did some work in the old Waytansea Hotel, and now the room numbers jump from 312 to 314 . Where there used to be a room, there's just perfect, seamless hallway, chair molding, baseboard, new power outlets every six feet, top-quality work. All of it code, except the room sealed inside.

And this Ocean Park man swirls the wine in his glass and says, 'I hope room 313 wasn't occupied at the time.'

Out in her car, there's a crowbar. They can have this door-way opened back up in five minutes. It's just drywall is all, she tells the man. Just Mr. Wilmot going crazy. and Real.

\footnotetext{
${ }^{7}$ Here one can observe the Lacanian coordinates of Palahinuk: Imaginary, Symbolic,
} 
When she puts her nose in the hole and sniffs, the wallpaper smells like a million cigarettes came here to die. Inside the hole, you can smell cinnamon and dust and paint. Somewhere inside the dark, you can hear a refrigerator hum. A clock ticks.

Written around and around the walls, it's always this same rant. In all these vacation houses. Written in a big spiral that starts at the ceiling and spins to the floor, around and around so you have to stand in the center of the room and turn to read it until you're dizzy. Until it makes you sick. ${ }^{8}$

These houses that contain Peter's rooms perform the function of civilisation: they are domestic spaces that solidify an attachment to a place, a time, a history. But it is as though the possibility of Peter's rooms was always there, hiding in plain sight: all the island's families knew about the planned terror, all the mainland visitors to Waytansea Island were implicated. The history of the homes carried this within the very act of dwelling inside them. Therefore, rather than positing the existence of discrete spaces of violence and violent acts, the reading of systemic violence allows us to capture the sense in which civilisation is itself the space of violence and terror. Peter Wilmot's lost rooms, his dark places, are the realisation of a possibility always-already present in the structure of Waytansea Island's civility.

The key to unfurling Palahniuk's writing is to engage with its formal character because here we find the limits of the conditions of his aesthetics and therein the event of violence. This critical gaze also facilitates the understanding of the nature of systemic violence in Palahniuk's novels. Diary is but one instance where we can observe how the Romantic Minimalist methods of Palahniuk enable him to write scenes of terror without passing judgement, shifting this labour onto the reader. Palahniuk's other books, such as Fight Club, Choke, Lullaby, Invisible Monsters, and, more recently, Pygmy, have their narratives disclosed in a space delimited by Palahniuk's Romantic Minimalism. In this disclosure, we encounter an in-aesthetic excess that interrupts the narrative by pushing the reader to intervene and pass judgement from within the narrative's aesthetics.

In an odd way, Palahniuk writes love and romance but in a violent way. The romantic content of his stories is always attached to the transgression of one or other social code, and this narrative process is supported by the hermeneutics of Diary in its critique of language. But what I have tried to demonstrate above is how this transgression is not subversive: the possibility for violence is enabled by civilisation itself and Palahniuk's literary Minimalism fosters a criticism of civility for refusing to acknowledge the immense forces that it barely conceals and repeatedly fails to regulate. To the Palahniukian perspective, the violent chaos of the Romantic vision of sublimely charged

8 Palahniuk, Diary, 26-27. 
Nature bubbles up to the surface of civilisation in acts of violence and terror. This perspective becomes visible when we critically engage with Palahniuk's writing. The systemic violence of Minimalist prose forces the reader to intervene and create a 'time for judgement', a purveyor's critique of civilisation. If, as readers, we never see the bullet coming, a critical engagement with Palahniuk's Diary shows us just how blind to systemic violence we really are. We cannot go back to some idyll third-person narrative once we know this, and this is what makes the work of Palahniuk valuable in both fictional and critical terms.

School of Humanities, Griffith University, Australia

\section{References}

Sigmund Freud, The Interpretation of Dreams, trans. by James Strachey (London: Penguin Books Ltd., 1991).

Chuck Palahniuk, Diary (London: Vintage, 2004).

Non-Fiction (True Stories) (London: Vintage, 2004). 